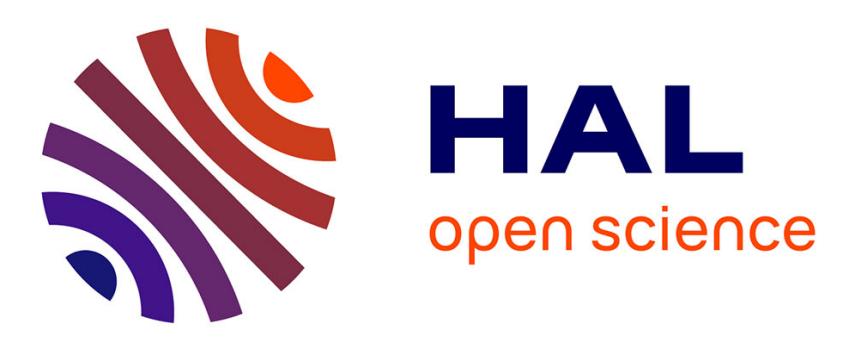

\title{
Peach aphid management in organic and conventional orchards: how to reconnect efficiency and ecology?
}

Servane Penvern, Joel Fauriel, Stephane Bellon

\section{To cite this version:}

Servane Penvern, Joel Fauriel, Stephane Bellon. Peach aphid management in organic and conventional orchards: how to reconnect efficiency and ecology?. Organic Fruit Conference, Jun 2008, Vignola, Italy. hal-02751300

\author{
HAL Id: hal-02751300 \\ https://hal.inrae.fr/hal-02751300
}

Submitted on 3 Jun 2020

HAL is a multi-disciplinary open access archive for the deposit and dissemination of scientific research documents, whether they are published or not. The documents may come from teaching and research institutions in France or abroad, or from public or private research centers.
L'archive ouverte pluridisciplinaire HAL, est destinée au dépôt et à la diffusion de documents scientifiques de niveau recherche, publiés ou non, émanant des établissements d'enseignement et de recherche français ou étrangers, des laboratoires publics ou privés. 


\title{
Peach aphid management in organic and conventional orchards : \\ How to reconnect efficiency and ecology ?
}

\author{
S. Penvern, J. Fauriel, S. Bellon \\ Servane.penvern@ avignon.inra.fr \\ INRA UR 767, Ecodevelopment Unit, 84914 Avignon, France
}




\section{Introduction}

- Peach in France : 16000 ha (316 ha in OF)

- Aphids $=>$ serious damage

Direct symptoms :

Leaves' deformation Reduced tree vigour
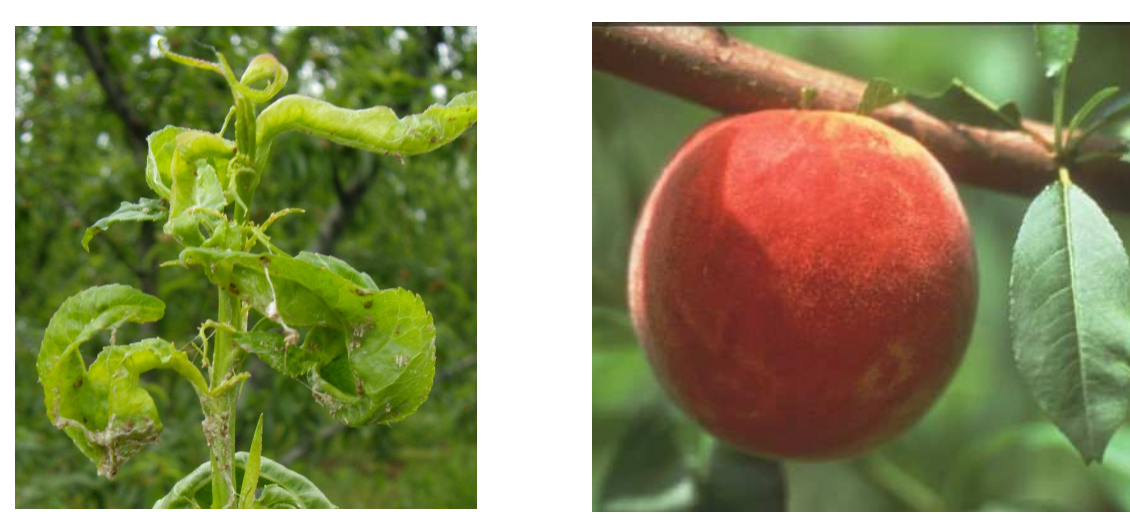

Undirect symptoms :

Plum Pox Virus

- Protection dominated by chemicals

$\Rightarrow$ Shift towards an agroecosystem approach

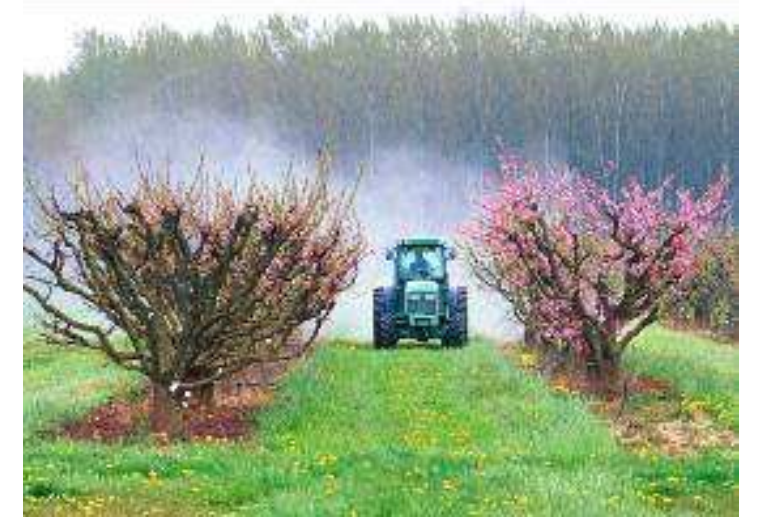




\section{The paradox between efficiency and ecology : Is there a best management strategy?}

- Identification of farmer's practices

- Characterisation of their strategy

- Assessment of its efficiency (impact on aphids) and ecological respect (impact on beneficials)

- Effect of the tree vigour (Price, 1991)? 


\section{Material \& Methods}

放Organic farms

is Conventional farms

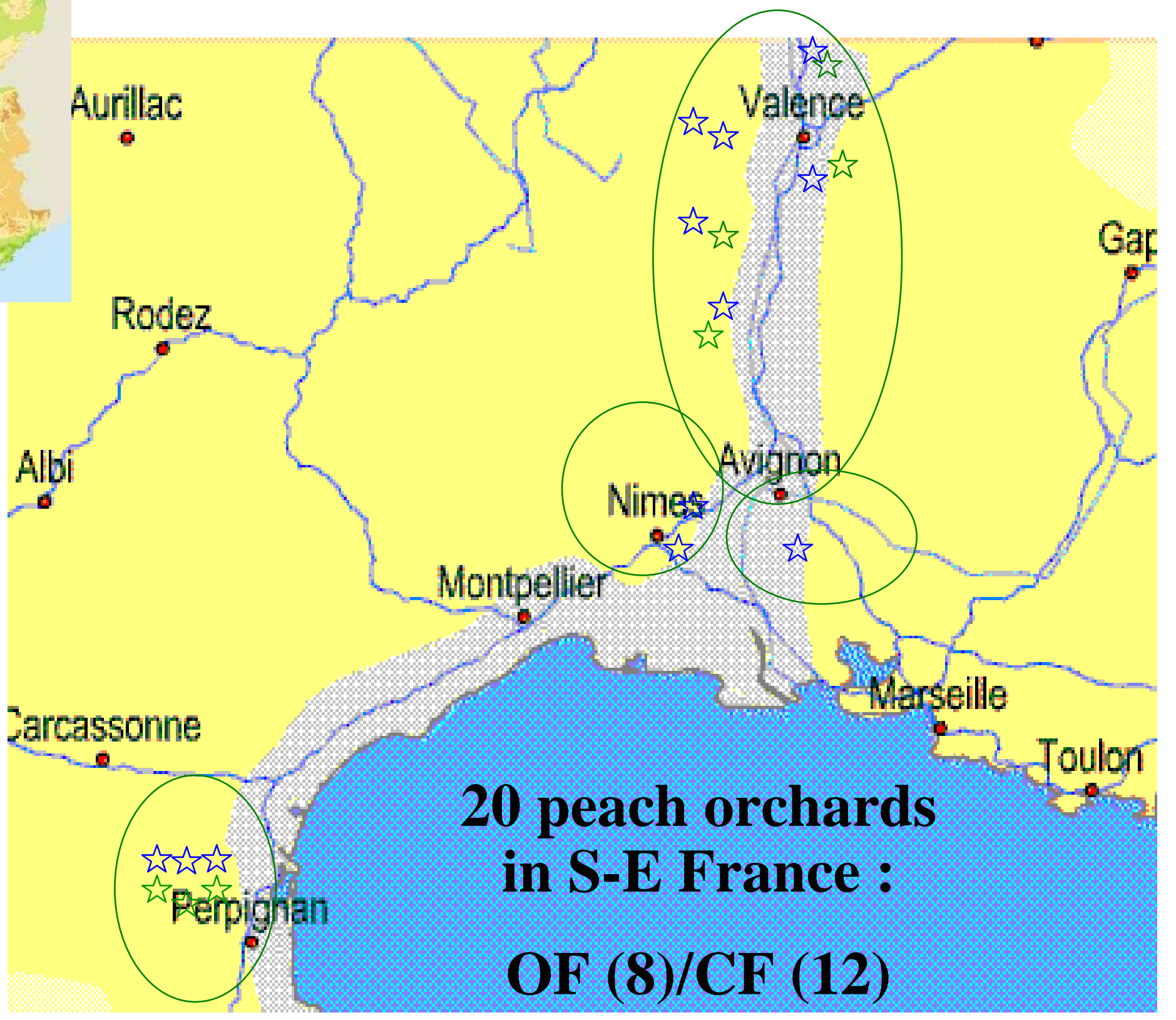




\section{Aphids' infestations (1)}

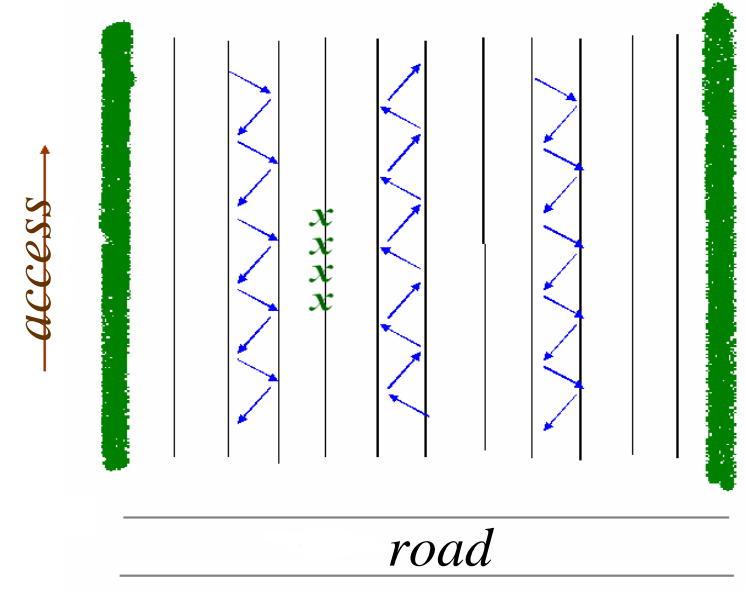

Leclant's classification (1970):

\begin{tabular}{|c|c|}
\hline $\begin{array}{c}\text { degree of aphid } \\
\text { infestation (d) }\end{array}$ & $\begin{array}{c}\text { Number of } \\
\text { aphids per shoot } \\
(\mathrm{N})\end{array}$ \\
\hline 0 & 0 \\
\hline 1 & $0<\mathrm{N}<5^{1}$ \\
\hline 2 & $5^{1}<\mathrm{N}<5^{2}$ \\
\hline 3 & $5^{2}<\mathrm{N}<5^{3}$ \\
\hline 4 & $5^{3}<\mathrm{N}<5^{4}$ \\
\hline 5 & $5^{4}<\mathrm{N}<5^{5}$ \\
\hline
\end{tabular}
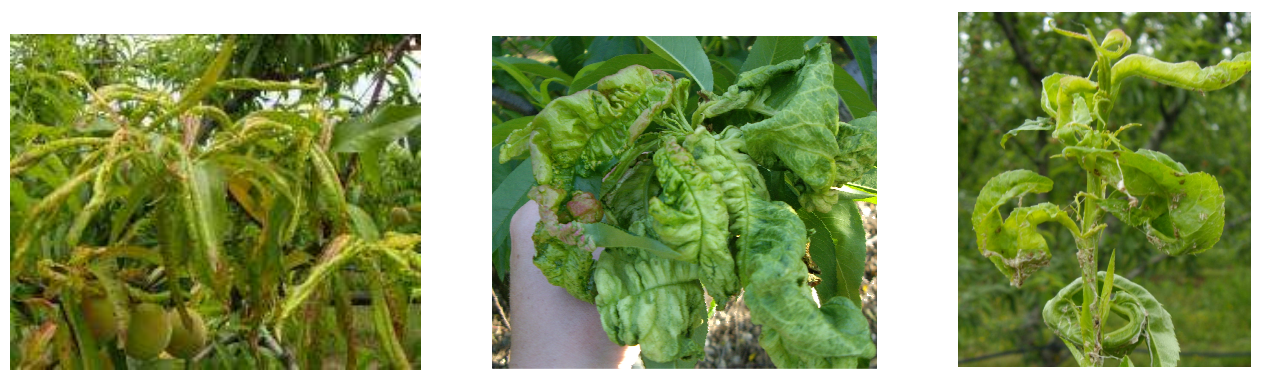

Aphid's community:

- Myzus persicae (Sulzer)

- Brachycaudus persicae (Passerini)

- Brachycaudus schwartzi (Börner)

- Hyalopterus amygdalii (Blanchard)

- Myzus varians Davidson

Infestation Index (Chen, 1997) :

$$
\mathrm{IF}=\Sigma 50\left(\mathrm{f}_{\mathrm{d}} \mathrm{x} \mathrm{d}\right) /\left(5 \times \Sigma 50 \times \mathrm{f}_{\mathrm{d}}\right)
$$$$
f_{d} \text { : frequency of } d
$$ 


\section{Impact on Aphids' antagonists (2)}

Antagonist's community :

Coccinellidae; Syrphydae; Hemerobiidae and Chrysopidae; Araneae; Earwigs; Aeolothripidae

$\Rightarrow \mathrm{H}$, shannon diversity index

$$
H=-\sum\left[p i \times \log _{2}(p i)\right]
$$

$\Rightarrow \mathrm{A}$, abundance index

$\mathrm{P}_{\mathrm{i}}$ : the fraction of the species

$\Rightarrow \mathrm{S}$, species richness

$$
\mathrm{E}=\mathrm{H} / \log _{2}(\mathrm{~S})
$$

$\Rightarrow \mathrm{E}$, evenness index
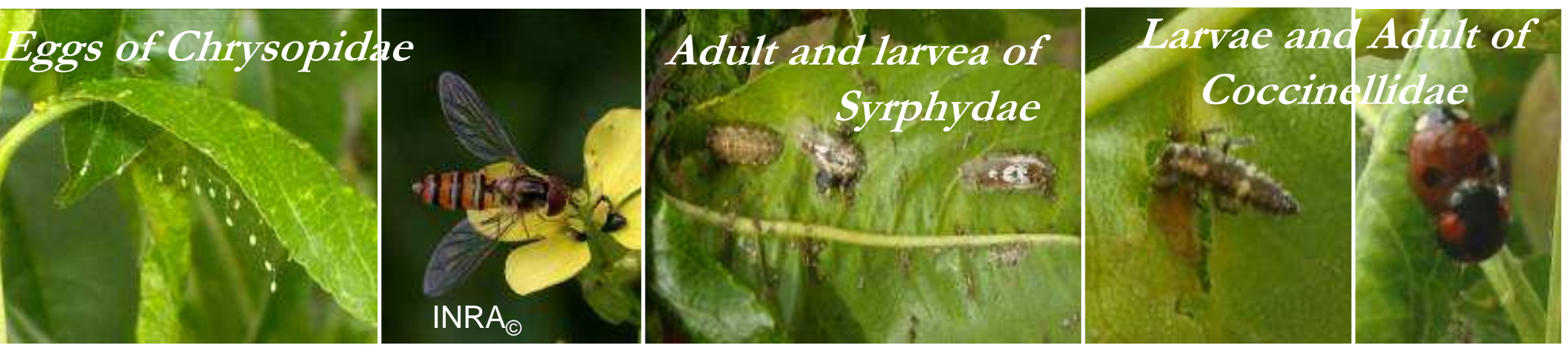


\section{Effect of the vigour (3)}

The morphological parameters monitored are:

- number of leaves $(\mathrm{Nf})$,

- shoot length (Lp),

- fruit diameter (Dfr),

- trunk perimeter (DT),

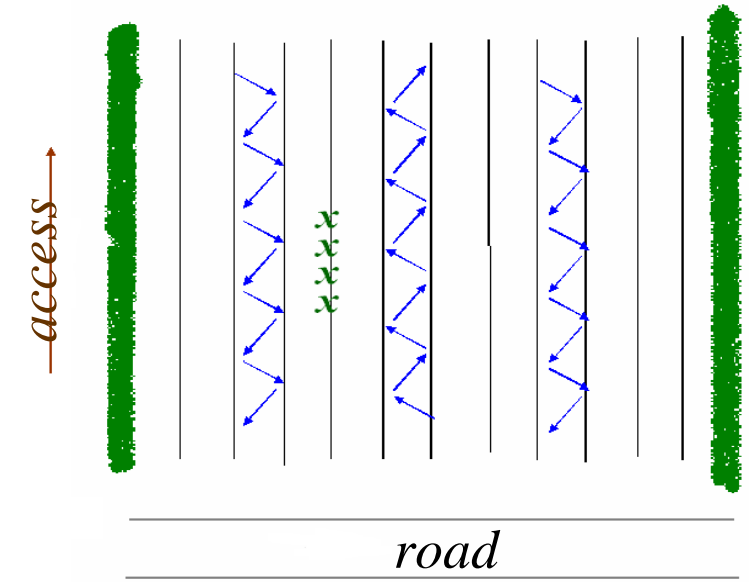

- number of water-sprouts on the trunk and on fruiting branches (Gmd)

- nitrogen-contents in leaves $(\mathrm{N})$.

Vigour index (IV):

$$
\text { IV }=\log (\text { Dfr_AUC x Lp_AUC x Nf_AUC x Gmd x N x DT) }
$$


Results 


\section{Farmer's practices (1)}

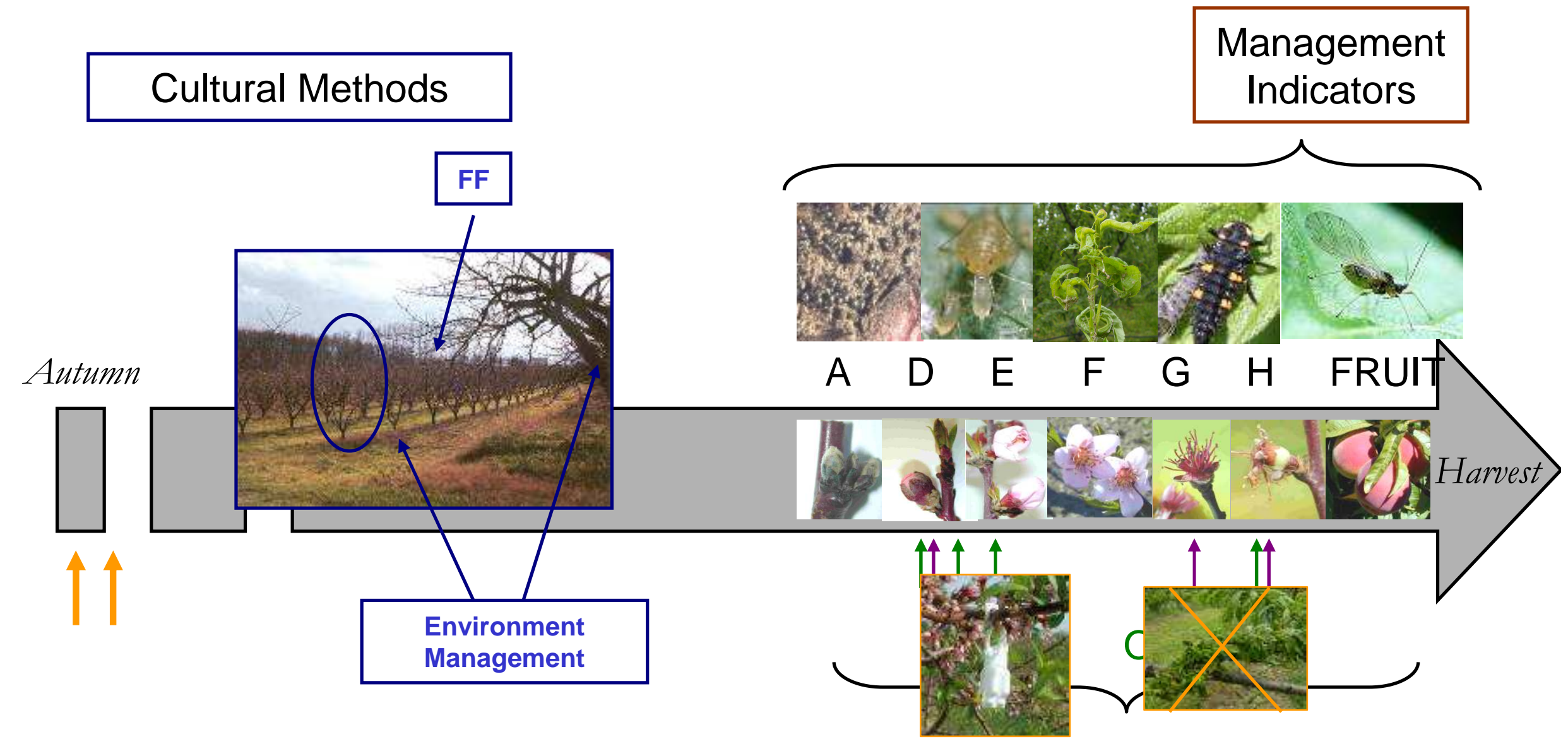

Altiriredtuletettrodods 


\section{Spray programs (2)}

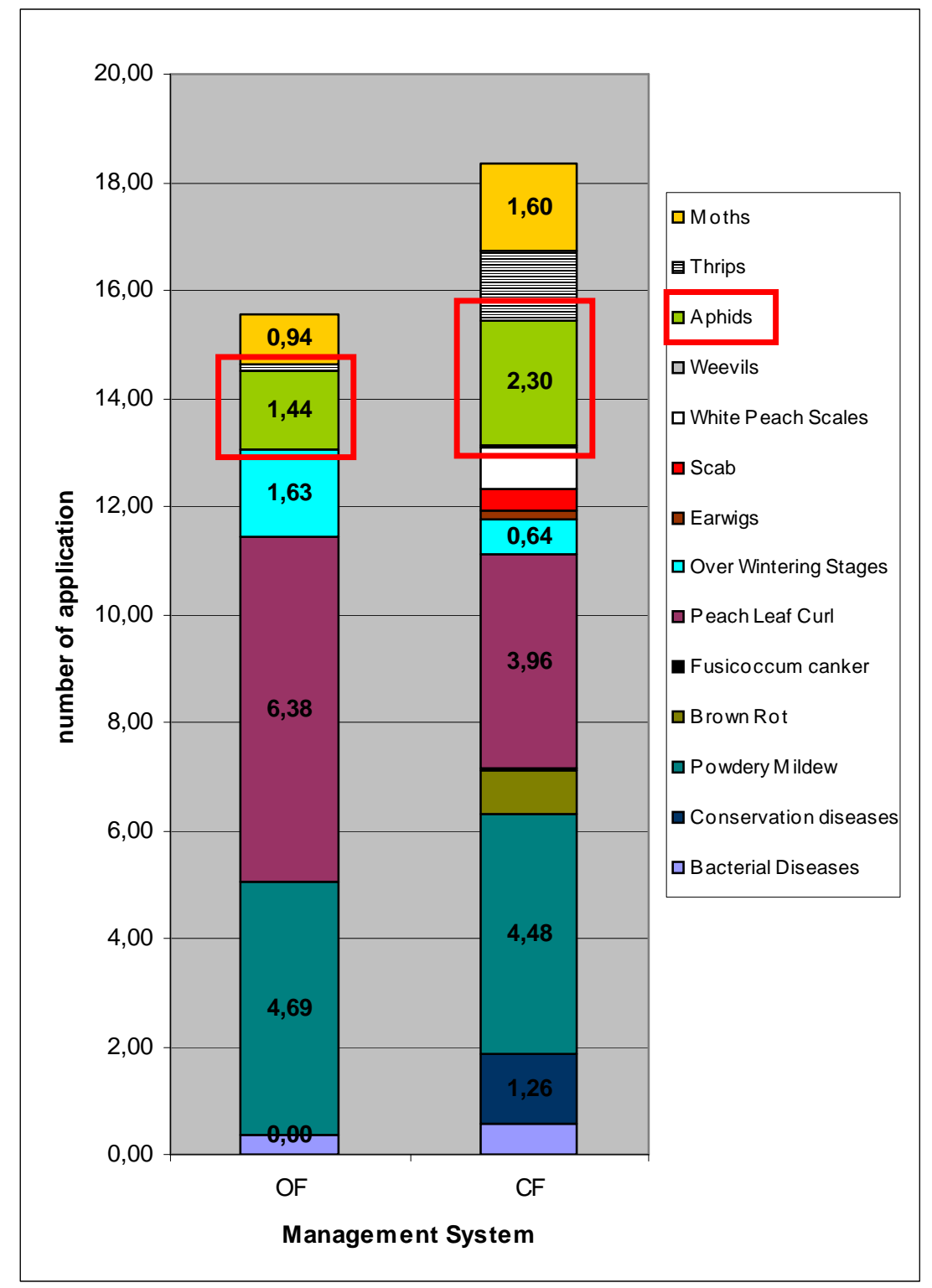




\section{Spray programs (2)}

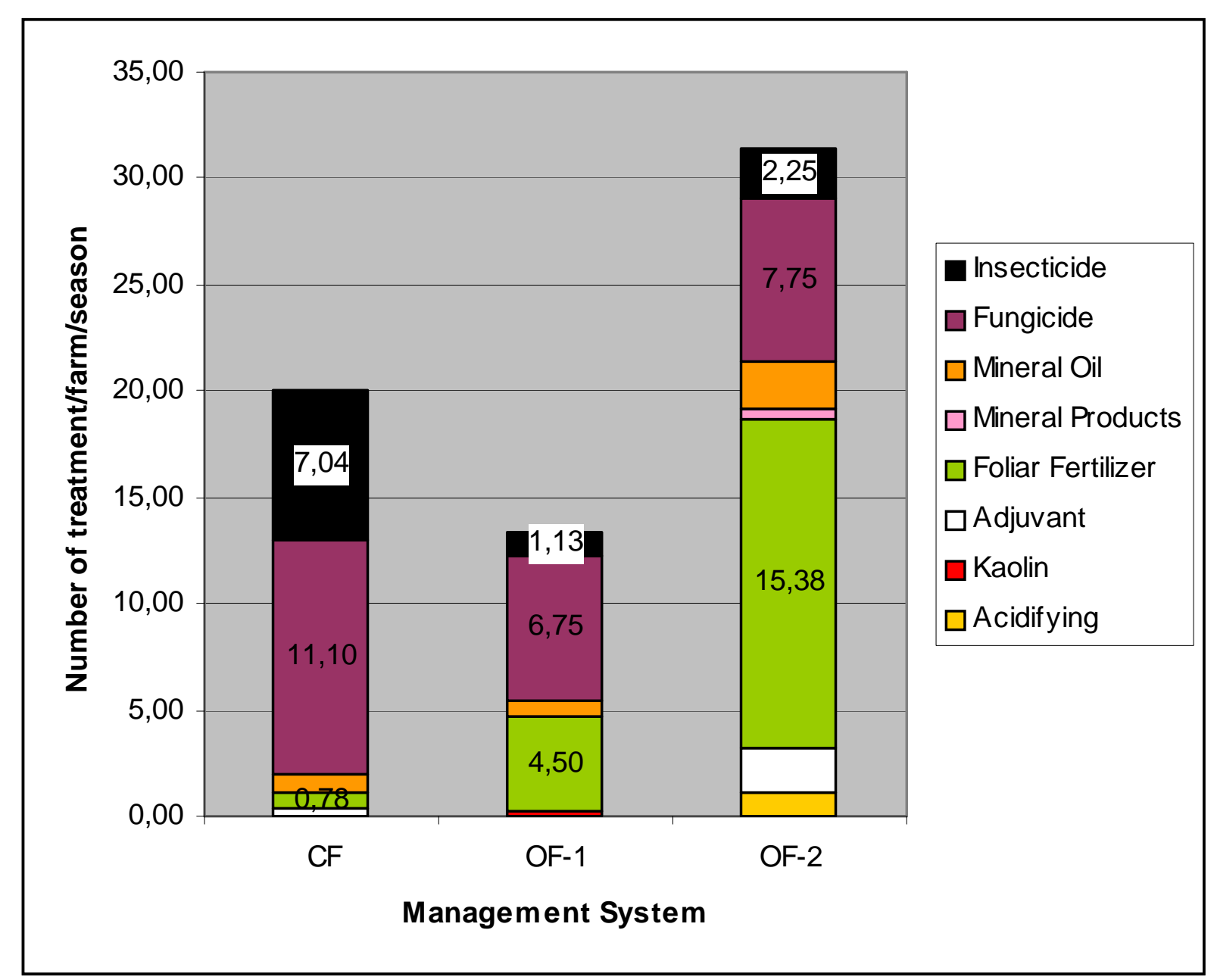

Two strategies can be distinguished in $\mathrm{OF}$ 


\section{Impact on Aphids (3)}

Aphids are more abundant and more diversified in OF
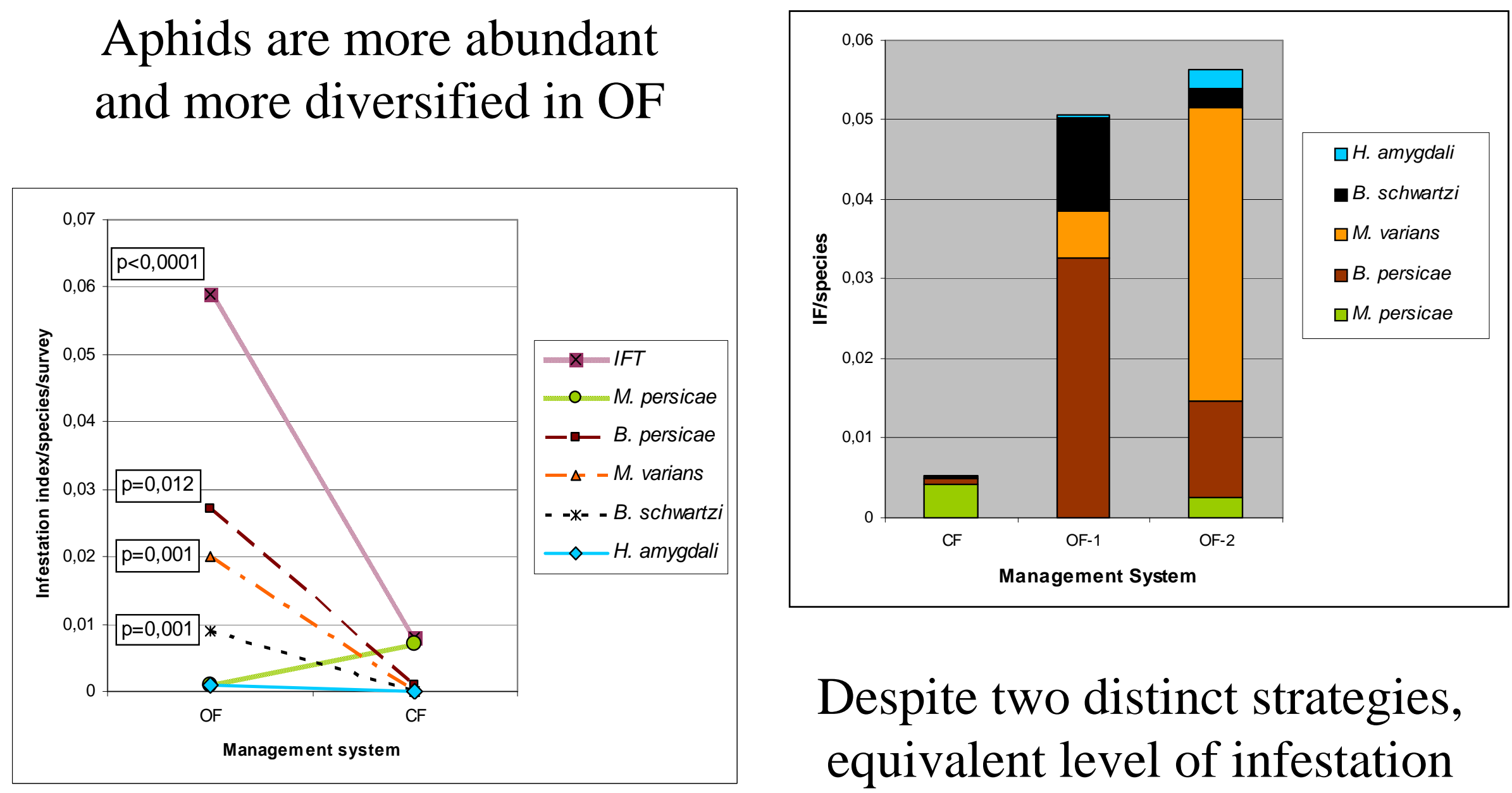

Despite two distinct strategies, equivalent level of infestation 


\section{Impact on beneficials (3)}

Aphid's antagonists are more abundant and more diversified in $\mathrm{OF}$

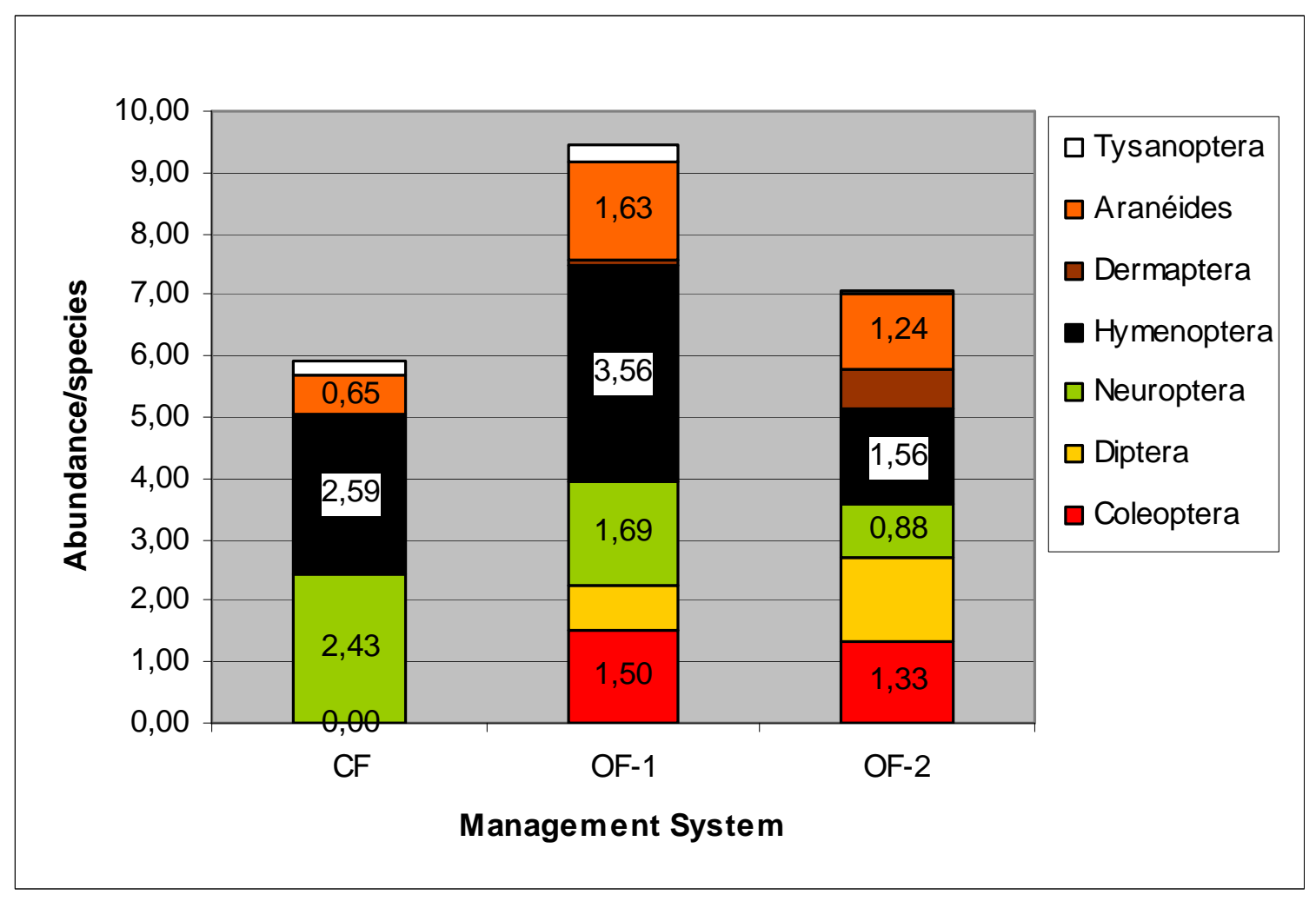

\begin{tabular}{r|r|r|r|r|r|}
\cline { 2 - 6 } \multicolumn{1}{c|}{} & B. Persicae & B. Schwartzi & H. amygdali & M. Varians & Total \\
\hline Coccinellidae & & 0,011 & & 0,017 & 0,001 \\
\hline Syrphydae & $\mathbf{0 , 0 2 7}$ & & 0,033 & 0,003 & 0,005 \\
\hline Araneidae & 0,045 & & & 0,031 & 0,033 \\
\hline Aeolothripidae & & & 0,015 & & \\
\hline A & & & & & 0,032 \\
\hline
\end{tabular}

$P$-value from of correlation of Spearman between aphids' infestations and antagonists' abundance. 


\section{Effect of cultural methods (4)}

- IV a good indicator?

$=>$ Only the $N$-content in leaves is not correlated to it, but no relation with the quantity of $N$-spread.

- Trees in OF tend to be less vigorous than in CF (ns)

- Vigour's effect on Aphid's infestation?

- No correlation between IV and IFT

- IFT linked to shoot's length, and number of leaves/shoot, and dose of $\mathrm{N}(\mathrm{p}=0.001)$

$=>$ But in all cases, the effect of the management system predominates 


\section{Conclusion}

- Conventional farmers limit their intervention to direct control

- Organic management strategies are more integrative, using many indicators and combining different methods

- $\mathrm{CF}$ is more efficient but OF preserve antagonists, thus respect ecological processes

- This can be explain through farmer's practices :

- Therapeutic toxic treatments OR preventive numerous treatments explains low infestation

- Non toxic, preventive treatments associated with cultural and alternative methods promote beneficials. 


\section{Conclusion}

- We can distinguish two strategies among organic farmers

- $\mathrm{OF}-1$ vs $\mathrm{OF}-2$ show better results $=>$ the closest from a total system approach, but not yet efficient (Brown, 1999)

- Other technics and methods available or on investigation to achieve better efficiency 

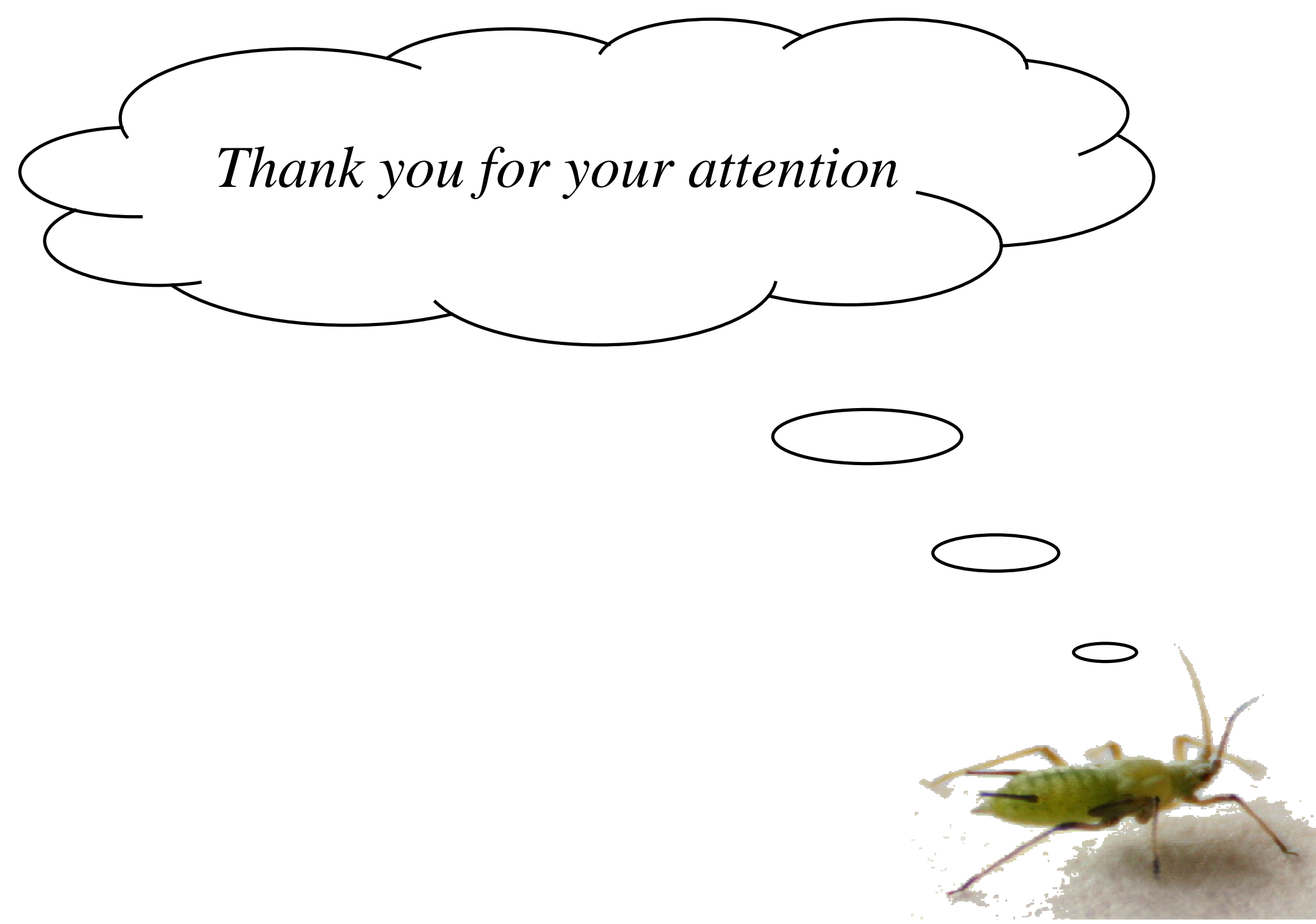